TELAGA BAHASA

Volume 5

No. 1 Juni 2017

Halaman 107-126

\title{
PERUBAHAN BENTUK KALIMAT PASIF BAHASA INGGRIS KE DALAM \\ BAHASA INDONESIA PADA NOVEL MORNING, NOON AND NIGHT KARYA SIDNEY SHELDON
}

\section{(A Form Changing of English Passive Voice into Indonesian in Morning, Noon, and Night: Novel Written by Sidney Sheldon)}

\author{
Mohammad Rizqi \\ Balai Bahasa Jawa Barat \\ Jalan Sumbawa Nomor 11, Bandung \\ Telepon: 082121982897 \\ pos-el: qqlennon@gmail.com
}

\begin{abstract}
Abstrak
Tulisan ini memfokuskan pembahasan pada terjemahan kalimat pasif dari bahasa Inggris ke dalam bahasa Indonesia. Kalimat aktif adalah kalimat yang subjeknya melakukan suatu tindakan, sedangkan kalimat pasif adalah kalimat yang subjeknya menderita (dikenai suatu tindakan) yang disebut dalam predikat. Kalimat aktif yang dapat diubah menjadi kalimat pasif adalah kalimat aktif yang mempunyai objek. Jadi kalimat tersebut merupakan kalimat yang memiliki verba transitif. Metode penelitian yang dilakukan adalah metode kualitatif dengan teknik analisis isi teks yang terdiri dari teks novel bahasa Inggris dan teks novel bahasa Indonesia. Penelitian ini merupakan deskripsi kajian pada novel yang mencakup terjemahan kalimat pasif dan perubahan tata bahasa yang terjadi. Tulisan ini memaparkan hasil kajian bentuk kalimat pasif dari bahasa sumber (bahasa Inggris) yang diterjemahkan ke dalam bahasa Indonesia. Hasil kajian menunjukkan bahwa ternyata tidak semua kalimat pasif bahasa sumber dapat diterjemahkan dalam bentuk kalimat pasif. Akan tetapi, kalimat itu bisa diterjemahkan dalam bentuk kalimat aktif oleh karena makna yang terkandung di dalamnya.
\end{abstract}

Kata kunci: penerjemahan, kalimat aktif, kalimat pasif, bentuk transitif, perubahan tata bahasa

\section{Abstract}

This paper focused on English passive voice translation into Indonesian. An active voice is a sentence where the subject performs the action stated by the verb, and a passive voice is the subject is acted upon by the verb. The 
active voice that can be switched into a passive voice is an active voice that has an object. Thus, the sentence is a transitive form. The method used is a qualitative method by using a technique of text content analysis and the text are English novel and its translation in Indonesian novel. This research is an analysis description on the novel that included passive voice translation and structural shift. This paper explained the results of the study of the passive sentences of the source language (English) translated into Indonesian. The results of the study show that not all of the passive sentences of the source language can be translated in the form of passive sentences in target language. Instead, the passive sentences can be translated in the form of active sentences because of the meaning contained.

Keywords: translation, active voice, passive voice, transitive form, structural shift

\section{PENDAHULUAN}

Melalui novel terjemahan, pembaca dapat mengenal budaya dan kehidupan bangsa lain yang kemudian memperkaya pengetahuan. Banyak hal yang harus diperhatikan dalam menerjemahkan sebuah cerita dari bahasa sumber ke bahasa sasaran. Salah satunya adalah memiliki gaya bahasa dan budaya yang bisa diterima oleh pembaca bahasa. Dalam menerjemahkan cerita novel yang berbahasa asing ke dalam bahasa Indonesia, cerita haruslah dapat diterima pembaca Indonesia, sehingga dapat bernilai sastra tinggi.

Penerjemahan adalah kegiatan mengalihkan pesan dari suatu bahasa (bahasa sumber) ke bahasa yang lain (bahasa sasaran). Penerjemahan masih mungkin untuk dilakukan karena setiap bahasa, per definisi, mempunyai sistem dan struktur yang "tertutup" (sui generis). Lebih lanjut, penerjemahan bukanlah sekadar menggantikan sebuah teks dalam bahasa sumber ke dalam bahasa sasaran, melainkan harus bertindak sebagai alat komunikasi, yang mempunyai maksud dan makna yang terkandung di dalamnya. Agar dapat menjadi alat komunikasi yang baik, penguasaan kalimat dalam bahasa sasaran perlu diperhatikan. Hal itu dimaksudkan supaya makna yang disampaikan pengarang cerita dapat disampaikan kepada pembaca bahasa sasaran dengan makna yang sama, sehingga cerita benar-benar menarik.

Pengalihan makna atau pesan dari bahasa sumber ke dalam bahasa sasaran pada dasarnya dilakukan dengan menggunakan leksikon dan struktur gramatikal yang sesuai dalam bahasa sasaran dan konteks budaya. Agar isi cerita dapat dipahami, tentu saja penerjemah harus menggunakan kalimat yang komunikatif. Secara umum dalam bahasa Inggris kalimat dapat dibedakan 
menjadi empat jenis, yaitu: (1) kalimat berita, (2) kalimat tanya, (3) kalimat perintah, dan

(4) kalimat seru. Di antara empat jenis kalimat universal tersebut yang paling banyak dipakai dalam buku dan tulisan ilmiah adalah kalimat berita (statement) dalam berbagai bentuknya, seperti: kalimat positif dan negatif, kalimat aktif dan pasif, kalimat langsung dan tidak langsung, kalimat biasa dan pengandaian, kalimat sederhana, majemuk, dan kompleks. Semua kalimat itu hanya dapat dipahami dengan baik sesuai dengan bentuknya yang berkaitan dengan waktu tindakan yang terkandung dalam kalimat itu terjadi dalam bahasa Inggris disebut tenses.

Tulisan ini memfokuskan pembahasan pada terjemahan kalimat pasif dari bahasa Inggris ke dalam bahasa Indonesia. Kalimat aktif adalah kalimat yang subjeknya melakukan suatu tindakan, sedangkan kalimat pasif adalah kalimat yang subjeknya menderita (dikenai suatu tindakan) dari yang disebut dalam predikat. Kalimat aktif yang dapat diubah menjadi kalimat pasif adalah kalimat aktif yang mempunyai objek. Jadi kalimat tersebut merupakan kalimat yang memiliki verba transitif (Azar; 1989). Contohnya: Someone has stolen my books (kalimat aktif dengan objek books); kalimat aktif ini dapat diubah menjadi kalimat pasif menjadi My books have been stolen.

Pemahaman tata bahasa Inggris penting dalam menerjemahkan kalimat ke dalam bahasa Indonesia tanpa mengurangi makna (Azar; 1992). Tidak bisa dimungkiri bahwa setiap terjemahan terdapat pergeseran makna, tetapi setiap penerjemah pastilah akan meminimalisasi pergeseran makna tersebut dengan mencari padanan kata yang paling tepat dalam bahasa sasaran sehingga tidak mengurangi isi cerita yang akan disampaikan oleh pengarang. Penerjemah dapat dinilai melakukan kesalahan dalam terjemahan hanya jika kesalahan itu sematamata kesalahan bahasa. Namun dalam hal lain, penerjemahan menyangkut soal kiat pribadi penerjemah dalam kapasitas retorika. Bahkan, dalam penerjemahan teks sastra faktor estetika dan selera memengaruhi proses penerjemahan.

Pemahaman tata Bahasa Indonesia pun tidak kalah penting. Penafsiran dalam bahasa Indonesia dilakukan dengan menggunakan verba berprefiks di- dan menggunakan verba tanpa prefiks di-. Akan tetapi, dalam penerjemahan bisa saja tidak menggunakan penafsiran yang sudah baku karena disesuaikan dengan makna yang terkandung di dalamnya, bahkan diterjemahkan dalam bentuk bukan kalimat pasif (kalimat aktif). 
Berdasarkan latar belakang yang telah diuraikan, masalah dalam penelitian ini dalah sebagai berikut.

1. Apakah kalimat pasif bahasa sumber tetap diterjemahkan sebagai kalimat pasif dalam bahasa sasaran?

2. Apakah bentuk kalimat menjadi pola yang utama dalam menerjemahkan?

Berdasarkan masalah yang telah diuraikan, tujuan penulisan ini adalah

1. Untuk mengetahui apakah kalimat pasif bahasa sumber tetap diterjemahkan sebagai kalimat pasif dalam bahasa sasaran

2. Untuk mengetahui apakah bentuk kalimat merupakan pola utama dalam menerjemahkan.

\section{METODE}

Metode penelitian yang dilakukan adalah metode kualitatif dengan teknik analisis isi teks yang terdiri dari teks novel bahasa Inggris dan teks novel bahasa Indonesia. Penelitian ini merupakan deskripsi kajian pada novel yang mencakup terjemahan kalimat pasif dan perubahan tata bahasa yang terjadi. Metode kualitatif adalah metode penelitian yang bertujuan membuat deskripsi, gambaran atau lukisan secara sitematis, faktual dan akurat mengenai fakta, sifat serta hubungan antarfenomena yang diselidiki secara kualitatif. Fakta yang dimaksud adalah data pada penerjemahan kalimat pasif dalam novel bahasa Inggris sebagai bahasa sumber dan dalam bahasa Indonesia sebagai teks bahasa sasaran dalam novel Morning, Noon and Night yang diterjemahkan oleh tim penerjemah PT Gramedia Pustaka Utama.

\section{TEORI}

Fokus penelitian adalah penerjemahan bentuk terjemahan kalimat pasif dalam novel bahasa Inggris ke dalam bahasa Indonesia. Translation atau penerjemahan selama ini didefinisikan melalui berbagai cara dengan latar belakang teori dan pendekatan yang berbeda. Catford (1965) menggunakan pendekatan kebahasaan dalam melihat kegiatan penerjemahan dan ia mendefinisikan sebagai, The replacement of textual material in one language (source Language) by equivalent textual material in another language (target Language), artinya, menerjemahkan makna suatu teks ke dalam bahasa lain sesuai dengan yang dimaksudkan pengarang.

Newmark (1981) juga memberikan definisi serupa, it is rendering the meaning of a text into another language in the way that the author intended the text, artinya menerjemahkan makna. Newmark (1988) juga mendefinisikan penerjemahan sebagai suatu keahlian. Lebih lanjut ia 
mengemukakan: Translation is a craft consisting in the attempt to replace a written message and/or statement in one language by the same message and/or statement in another language. Penerjemahan merupakan suatu keahlian untuk mengubah pesan tertulis dan/atau pernyataan dari satu bahasa ke bahasa yang lain dengan pesan dan/atau pernyatan yang sama (Newmark; 1991).

Menurut Nida dan Taber, yang paling penting dalam penerjemahan adalah beralihnya pesan atau makna bahasa sumber ke dalam bahasa sasaran dan, sedapat mungkin, menyesuaikan bentuknya, serta diungkapkan sewajar mungkin, seperti yang mereka katakan, Translating consists in reproducing in the receptor language the closet natural equivalent of the source language message, first in terms of meaning and secondly in terms of style (2003).

Moentaha (2006) mendefinisikan terjemahan sebagai proses penggantian teks dalam bahasa sumber dengan teks dalam bahasa sasaran tanpa mengubah tingkat isi teks bahasa sumber. Namun perlu ditekankan bahwa pengertian "tingkat isi" harus dipahami secara maksimal dan luas, yakni tidak hanya yang menyangkut arti dasar (material meaning), ide atau konsepsi yang terkandung dalam tingkat isi, tetapi juga semua informasi yang ada dalam teks bahasa sumber, semua norma bahasa, seperti makna leksikal, makna gramatikal, dan nuansa stilistis/ nuansa ekspresif.

Penerjemahan adalah proses penggantian atau transformasi pesan dari bahasa sumber ke dalam bahasa sasaran dengan memperhatikan kaidah yang berlaku pada bahasa sasaran. Kesepadanan makna adalah hal yang penting dalam proses penerjemahan. Untuk mendapatkan terjemahan yang memiliki makna yang sepadan, penerjemah harus memahami bahasa sumber, baik dari segi gramatikal maupun leksikal. Penerjemahan ke dalam bahasa sasaran pun harus bersifat komunikatif dan ekspresif (Hasibuan; 1991).

Ada ahli yang beranggapan bahwa bahasa adalah sebuah sistem simbol yang bersifat manasuka dan dengan sistem itu suatu kelompok sosial bekerja sama (Machali, 2000). Ada juga ahli bahasa yang beranggapan bahwa bahasa adalah sebuah sistem berstruktur mengenai bunyi dan urutan bunyi bahasa yang sifatnya manasuka, yang digunakan, atau yang dapat digunakan dalam komunikasi antar individu oleh sekelompok manusia dan yang secara tuntas memberi nama benda, peristiwa, dan proses dalam lingkungan hidup manusia.

Berdasarkan dua definisi di atas dapatlah dikatakan sebagai berikut. Pertama, bahasa merupakan sistem yang mempunyai struktur sebagaimana halnya dengan sistem 
lain. Bahasa memiliki pola dan berdasarkan pola itulah bahasa digunakan. Kedua, bahasa merupakan sistem bunyi yang bersifat manasuka. Bunyi bahasa tercipta secara manasuka dan bunyi ini tidak memiliki makna, bunyi itu kemudian disusun pula secara manasuka sehingga kemudian timbul kata yang membawa makna tertentu. Ketiga, bahasa itu memungkinkan terjadinya komunikasi antarpribadi. Komunikasi inilah yang merupakan fungsi utama bahasa. Sebagai alat komunikasi bahasa bertugas untuk menyampaikan informasi atau sebagai alat untuk menerima informasi.

\section{Kalimat Aktif dan Kalimat Pasif}

Kalimat aktif adalah kalimat yang subjeknya melakukan suatu tindakan, sedangkan kalimat pasif adalah kalimat yang subjeknya menderita (dikenai suatu tindakan) dari apa yang disebutkan dalam predikat. Alwi (2003) mengemukakan pengertian aktif dan pasif dalam kalimat menyangkut beberapa hal: (1) macam verba yang menjadi predikat, (2) subjek dan objek, dan (3) bentuk verba yang dipakai. Penafsiran dalam bahasa Indonesia dilakukan dengan dua cara: (1) menggunakan verba berprefiks di- dan (2) menggunakan verba tanpa prefiks di-. Tidak semua kalimat aktif dapat dijadikan pasif. Yang dapat diubah menjadi kalimat pasif adalah kalimat aktif yang mempunyai objek.
Kalimat perintah (command) dan kalimat seru (exclamation) juga tidak dapat dijadikan pasif.

\section{Kalimat Pasif dalam Bahasa Inggris}

Kalimat pasif dalam bahasa Inggris

selalu menggunakan to be dengan past participle + kata kerja bentuk ketiga: to do did-done. Bentuk kata kerja ini digunakan dalam semua kalimat pasif dalam bahasa Inggris. Be dapat berupa berbagai bentuk sesuai dengan tenses: am, is, are, was, were, has been, have been, will be, dan lain-lain. Rumus bentuk pasif menurut berbagai tense adalah sebagai berikut.

present tense: am/is/are + past participle, misalnya: "is translated"

> past tense: was/were + past participle, misalnya: "was written" $>$ present perfect tense: have/has + been + past participle, misalnya: "has been promoted" past perfect tense: had + been + past participle, misalnya: "had been decreased"

present future tense: will/shall + be + past participle, misalnya "will be taught"

past future tense: would/should + be + past participle, misalnya "would be sold" 
$>$ present continuous tense: am/is/are + being + past participle, misalnya: "is being taught"

past continuous tense: was/were + being + past participle, misalnya:

"was being thrown".

modal auxiliaries: modals + be + past participle, misalnya: “can be understood", "should be studied", "may be omitted", "must be transferred"

Beberapa jenis Kalimat Pasif adalah sebagai berikut:

(a) Kalimat pasif yang pelakunya (doer, agent) tidak dikenal, contoh: Passive: One of our windows was broken Active: Someone broke one of our windows.

(b) Kalimat pasif yang pelakunya tidak jelas atau tidak penting. Contoh:

Passive: English is spoken all over the world Active: People of all over the world speak English.

(c) Kalimat pasif yang pelakunya diketahui atau diberi tekanan. Contoh:

Passive: The fish is being eaten by the cat Active: The cat is eating the fish. (d) Kalimat Pasif yang berarti keadaan.

Bentuk kata kerja to be-verb -ed yang dikenal sebagai bentuk kalimat pasif tidak selalu menunjukkan suatu perbuatan, melainkan ada yang menunjukkan suatu keadaan. Contoh kalimat pasif yang menunjukkan perbuatan: The door was opened by a thief by force. Contoh kalimat pasif yang menunjukkan keadaan: The small child is already bored with his new toy. Kalimat pasif yang berarti keadaan disebut juga Stative Passive (Penggunaan past participle sebagai ajektif/kata sifat). Be dapat diikuti oleh adjektiva (adjective). Adjektiva ini mendeskripsikan atau memberi informasi tentang subjek kalimat. Be dapat diikuti dengan sebuah past participle (bentuk pasif). Past participle tersebut sering kali seperti adjektiva. Past participle ini mendeskripsikan atau memberi penjelasan tentang subjek kalimat. Past participle digunakan sebagai adjektiva dalam beberapa hal umum dan dalam ungkapan sehari-hari. Kadang-kadang past participle ini diikuti kata depan (preposisi) tertentu dan objek.

Contoh:

Ann is married to Alex

I don't know where I am. I am lost.

The window is broken 
Kalimat Aktif dan Pasif Sesuai dengan Tenses

Kalimat aktif dan pasif dapat dibuat sebanyak tenses yang ada. Jika kalimat aktif diubah menjadi pasif, atau sebaliknya, tenses tidak boleh diubah. Dengan kata lain, tenses kalimat aktif dan pasif harus sama. Contoh bentuk kalimat pasif dalam berbagai tenses adalah sebagai berikut:

Simple Present: Mary helps John --> John is helped by Mary

Present Progressive: Mary is helping John --> John is being helped by Mary

Present Perfect: Mary has helped John --> John has been helped by Mary

Simple Past: Mary helped John --> John was helped by Mary

\section{Kalimat Pasif dalam Bahasa Indonesia}

Alwi (2003) mengatakan bahwa pengertian aktif dan pasif dalam kalimat menyangkut beberapa hal: (1) macam verba yang menjadi predikat, (2) subjek dan objek, dan (3) bentuk verba yang dipakai. Beberapa contoh kalimat aktif dalam bahasa Indonesia adalah sebagai berikut:

(1) Pak Toha mengangkat seorang asisten baru.

(2) Ibu Gubernur akan membuka pameran itu.

(3) Pak Saleh harus memperbaiki dengan segera rumah tua itu.

(4) Kamu dan saya harus menyelesaikan tugas ini.

(5) Saya sudah mencuci mobil itu.

(6) Kamu mencium pipi anak itu.

Semua contoh kalimat menunjukkan bahwa verba yang terdapat dalam tiap kalimat adalah verba transitif, baik yang ekatransitif maupun yang dwitransitif. Karena kalimat itu transitif, paling tidak, ada tiga unsur wajib di dalamnya, yakni subjek, predikat, dan objek. Verba transitif yang dipakai adalah dalam bentuk aktif, yakni verba yang memakai prefiks meng-.

Pemasifan dalam bahasa Indonesia dilakukan dengan dua cara, yaitu (1) menggunakan verba berprefiks di- dan (2) menggunakan verba tanpa prefiks di-. Jika simbol S digunakan untuk subjek, $\mathrm{P}$ untuk predikat, dan $\mathrm{O}$ untuk objek, kaidah umum untuk pembentukan kalimat pasif dari kalimat aktif dalam bahasa Indonesia adalah sebagai berikut. Cara pertama, (1) pertukarkanlah $\mathrm{S}$ dengan $\mathrm{O}$, (2) gantilah prefiks meng- dengan di- pada P, (3) tambahkan kata oleh di muka unsur yang tadinya S. Untuk contoh kalimat aktif dapat diubah menjadi kalimat pasif sebagai berikut. 
Kalimat (1): Seorang asisten baru diangkat oleh Pak Toha.

Kalimat (1) dapat juga dibuat: Seorang asisten baru diangkat Pak Toha.

Kalimat (2): Pameran itu akan dibuka oleh Ibu Gubernur.

Keberterimaan kalimat (1) dalam selesaikan', yang dibentuk dengan cara bentuk yang pertama dan kedua kedua, kita tolak sebagai bentuk pasif kalimat menunjukkan bahwa kehadiran bentuk oleh (4) di atas. Kehadiran kata oleh pada kalimat pada kalimat pasif bersifat manasuka. Akan (4) adalah wajib, jadi kalimat pasif yang tetapi, jika verba predikat tidak diikuti berterima dari kalimat (4) adalah " Tugas itu langsung oleh pelengkap pelaku (yang harus diselesaikan oleh kamu dan saya' sebelumnya subjek kalimat aktif), maka Cara kedua, padanan pasif dari kalimat aktif bentuk oleh wajib hadir. Atas dasar itulah maka bentuk kalimat (3) berikut kita terima: Kalimat (3) Rumah tua itu harus diperbaiki dengan segera oleh Pak Saleh. Sedangkan bentuk tanpa kata 'oleh' tidak bisa diterima sebagai bentuk kalimat pasif ('Rumah tua itu harus diperbaiki segera Pak Saleh'). Pemasifan dengan cara pertama itu umumnya digunakan jika subjek kalimat aktif berupa nomina atau frasa nominal seperti contoh kalimat (1)-(5) di atas, jika subjek kalimat pasif berupa pronominal persona, padanan pasifnya umumnya dibentuk dengan cara kedua. Akan tetapi, kalau subjek kalimat aktif itu berupa gabungan pronominal dengan pronominal atau frasa lain, maka padanan pasifnya dibentuk dengan cara pertama itu. transitif yang subjeknya berupa pronominal dibentuk dengan cara kedua. Adapun kaidah pembentukan kalimat pasif cara kedua itu adalah sebagai berikut: (1) pindahkan $\mathrm{O}$ ke awal kalimat, (2) tanggalkan prefiks mengpada $\mathrm{P}$, (3) pindahkan $\mathrm{S}$ ke tempat yang tepat sebelum verba. Cara kedua ini bila diterapkan pada contoh kalimat (5), bentuk kalimat pasifnya adalah 'Mobil itu sudah saya cuci'. Dengan cara yang sama, dapat pula diperoleh bentuk pasif dari contoh kalimat (5) sebagai padanan kalimat aktifnya adalah: 'Pipi anak itu kamu cium'

Jika subjek kalimat aktif transitif berupa pronominal persona ketiga atau nama diri yang relatif pendek, padanan pasifnya dapat dibentuk dengan cara pertama atau Karena itulah bentuk kalimat pasif kalimat kedua sepeti tampak pada contoh berikut:

(4) 'Tugas ini harus kamu dan saya

Contoh (a) aktif: Mereka akan membersihkan ruangan ini pasif 1: Ruangan ini akan dibersihkan (oleh) mereka 
pasif 2: Ruangan ini akan mereka bersihkan.

Contoh (b) aktif : Dia sudah membaca buku itu.

pasif 1: Buku itu sudah dibaca olehnya/(oleh) dia

pasif 2: Buku itu sudah dibacanya/dia baca.

Contoh (c) aktif: Ayah belum mendengar berita duka itu.

pasif 1: Berita duka itu belum didengar (oleh) ayah.

pasif 2: Berita duka itu belum ayah dengar.

Jika subjek kalimat aktif transitif itu panjang, padanan kalimat pasifnya dibentuk dengan cara pertama. Jadi, bentuk seperti "Berita duka itu belum didengar oleh Susilowati" tidak dapat diubah menjadi "Berita duka itu belum Susilowati dengar".

Pembentukan kalimat pasif dengan cara kedua dari kalimat aktif transitif yang subjeknya berupa pronominal persona ketiga atau nama diri pada umumnya terbatas pada pemakaian sehari-hari. Pronomina aku, engkau, dan dia (yang mengikuti predikat) pada kalimat pasif cenderung dipendekkan menjadi ku-, kau-, dan -nya seperti pada contoh kalimat berikut:

a.1. Surat itu baru aku terima kemarin

a.2. Surat itu baru kuterima kemarin.

b.1. Buku ini perlu engkau baca.

b.2. Buku ini perlu kau baca.

c.1. Pena saya dipinjam oleh dia.

c.2. Pena saya dipinjam olehnya

Perubahan kalimat aktif transitif yang mengandung kata seperti ingin atau mau cenderung menimbulkan pergerseran makna, contoh: Andi ingin mencium Tuti; Tuti ingin dicium Andi. Pada kalimat pertama adalah kalimat aktif, jelas bahwa yang ingin melakukan perbuatan mencium adalah Andi, tetapi pada kalimat kedua, orang cenderung menafsirkan bahwa yang menginginkan ciuman itu adalah Tuti dan bukan Andi. Tafsiran makna kalimat pasif yang berbeda dengan makna padanan kalimat aktif itu timbul karena kodrat kata ingin yang cenderung dikaitkan dengan unsur di sebelah kiri yang mendahuluinya. Hal ini tampak lebih nyata pada keganjilan pasangan kalimat 'Andi ingin mencuci mobilnya' 'Mobilnya ingin dicuci Andi'

Arti pasif dapat pula bergabung dengan unsur lain seperti unsur ketaksengajaan. Jika kalimat aktif diubah menjadi kalimat pasif dan dalam kalimat pasif itu terkandung pula pengertian bahwa perbuatan yang dinyatakan oleh verba itu mengandung unsur yang tak sengaja, maka bentuk prefiks yang dipakai untuk verba 
bukan lagi di-, melainkan ter-. Perhatikan perbedaan kalimat (1) dan kalimat (2) yang berikut ini:

(1) a. Penumpang bus itu dilempar ke luar.

(1) b. Penumpang bus itu terlempar ke luar.

(2) a. Dia dipukul kakaknya.

(2) b. Dia terpukul kakaknya.

Kalimat (1a dan 2a) menunjukkan bahwa seseorang melakukan perbuatan itu dengan niat dan kesengajaan. Sebaliknya, kalimat (1b dan 2b) mengacu ke suatu keadaan atau ke ketidaksengajaan si pelaku perbuatan. Pada kalimat (1b) mungkin saja penumpang tadi terlempar oleh orang lain, atau mungkin juga oleh guncangan bus yang terlalu besar.

Di samping makna ketaksengajaan itu, verba pasif yang memakai 'ter-' juga dapat menunjukkan kekodratan; artinya, kita tidak memasalahkan siapa yang melakukan perbuatan tersebut sehingga seolah-olah sudah menjadi kodratlah bahwa sesuatu harus demikian keadaannya.

Contoh kalimat berikut:

(A) Gunung Merapi terletak di Pulau Jawa.

(B) Soal ini terlepas dari rasa senang dan tidak senang.
Pada contoh (A) dan (B) tidak ada unsur sengaja atau tidak sengaja, dan kita pun tidak memasalahkan siapa yang meletakkan gunung itu atau yang melepaskan soal ini.

Bentuk kalimat pasif lain yang bermakna adversative tampak pada contoh berikut:

(C) 1. Soal itu diketahui oleh orang tuanya.

(C) 2. Soal itu ketahuan oleh orang tuanya.

(D) 1. Partai kita dimasuki unsur kiri.

(D) 2. Partai kita kemasukkan unsur kiri.

Di sini perlu ditekankan bahwa makna kalimat yang predikatnya memakai ke-an ini adalah pasif dengan tambahan makna adversatif, yakni makna yang tidak menyenangkan.

\section{Teori Perubahan Tata Bahasa (Structural Change) dalam Kalimat Pasif}

Dalam menerjemahkan teks dari bahasa Indonesia ke bahasa Inggris, bentuk kalimat pasif sebaiknya dikuasai oleh penerjemah karena di sinilah letak kesalahan sintaksis. Dalam bahasa Inggris kata kerja dalam kalimat pasif mempunyai beragam bentuk sesuai dengan tenses. Secara umum rumus bentuk tersebut bisa disimpulkan sebagai - kata kerja pembantu (auxiliary $v e r b)+$ indikasi pasif + past participle. Kata 
kerja utama (main verb) dalam kalimat pasif harus berbentuk past participle. Dalam kalimat pasif, subjek kata kerja adalah objek pada kalimat aktif yang mana berarti bahwa subjek yang sebenarnya bukan pelakunya, ia hanya subjek kalimat. Dalam kalimat pasif, pelakunya diungkapkan dengan frasa "oleh". Namun frasa tersebut boleh dihilangkan karena sudah jelas siapa pelaku kata-kerja tersebut.

Kata kerja pasif bahasa Inggris diterjemahkan ke dalam bahasa Indonesia dengan menggunakan awalan di- atau ter- di depan kata kerja. Ter- mempunyai makna konotasi bahwa perbuatan tersebut tidak disengaja. Contohnya The child was struck by a car; 'Anak itu tertabrak oleh mobil'. Dalam kalimat itu, biasanya mobil tidak dengan sengaja menabrak seorang anak. Hal itu terjadi karena ketidaksengajaan.

Beberapa kajian dan penelitian terjemahan yang membahas karya sastra seperti novel telah dilakukan. Salah satunya oleh Darmawati dengan judul tulisan "Alih Bahasa Novel Dear John: Masalah Bentuk dan Makna. Dalam tulisan itu, darmawati menganalisi proses alih bahass novel karya Nicholas Spark itu dengan tujuan menemukan apakaah alih bahasa tersebut sudah memenuhi syarat-syarat penerjemahan yang baik. Sayangnya, tulisan tersebut masih membahas proses alih bahasa (dari bahasa
Inggris ke bahasa sasaran -bahasa Indonesia) secara umum, dengan kata lain belum memfokuskan ke bentuk penerjemahan kalimat pasif misalnya. Oleh karena itu, penulis tertarik mengangkat judul ini.

\section{HASIL DAN PEMBAHASAN}

Data diperoleh dari novel Morning, Noon and Night versi bahasa Inggris yang ditulis oleh Sidney Sheldon. Penerjemah novel ini adalah Hendarto Setiadi. Novel yang terdiri dari 35 bab dengan 388 halaman ini diterjemahkan ke dalam 35 bab 433 halaman. Semua kalimat pasif bahasa Inggris berpola subject + be + past participle didata, kemudian dicari hasil penerjemahannya dalam novel "Pagi, Siang dan Malam". Tahap selanjutnya adalah melakukan pengelompokan yang terdiri dari tiga kelompok, yaitu: (1) terjemahan yang menggunakan pola kata kerja pasif yang berawalan di-; (2) terjemahan yang menggunakan pola kata kerja pasif yang berawalan ter-; dan (3) terjemahan bukan keduanya.

Data penelitian adalah data kalimat pasif novel Morning, Noon and Night karya Sidney Sheldon. Novel terdiri atas 35 chapter dengan 388 halaman seluruhnya.

Semua data yang disajikan berasal dari novel yang berbahasa Inggris dengan pola kalimat pasif yang memiliki kata kerja 
be + past participle untuk semua jenis dan bentuk tenses. Terdapat 268 kalimat pasif di dalam novel bahasa sumber.

Setelah kalimat pasif bahasa sumber didata, didata pula hasil penerjemahan dalam novel terjemahannya "Pagi, Siang dan Malam" (dalam bahasa Indonesia). Semua data kalimat pasif dalam bahasa Inggris diterjemahkan ke dalam bahasa Indonesia dalam beberapa pilihan bentuk kalimat. Dari hasil penelitian, ternyata terdapat 3 kelompok yang telah disebutkan.

Oleh penulis, kelompok 3 dipersempit menjadi kelompok $3 a$ dan $3 b$ untuk memudahkan penelitian karena jumlah data kelompok 3 ini menyamai jumlah kelompok 1. Seluruh data kalimat pasif yang terdapat dalam novel ini berjumlah 268 kalimat, yaitu 120 kalimat terjemahan verba di+kata kerja (kelompok 1), 27 kalimat terjemahan verba ter+kata kerja (kelompok 2), 17 kalimat terjemahan verba ber+kata kerja (kelompok 3a) dan 104 kalimat terjemahan lain-lain (kelompok 3b). Untuk kelompok $3 b$ ini termasuk di dalamnya terjemahan kalimat pasif bahasa Inggris menjadi kalimat aktif dalam bahasa Indonesia, misalnya: dalam chapter thirty four page 429 kalimat pasifnya: “... while you are being questioned." diterjemahkan menjadi: "....saat menjawab pertanyaanpertanyaan kami."

Sebaran persentasi data tersebut terdapat pada Tabel 1 berikut.

\begin{tabular}{|l|l|r|l|}
\hline Kelompok & \multicolumn{1}{|c|}{ Terjemahan } & Jumlah Kalimat Pasif & \multicolumn{1}{c|}{$\%$} \\
\hline 1 & Kata kerja yang berawalan 'di-' & 120 & 44,78 \\
\hline 2 & Kata kerja yang berawalan 'ter-' & 27 & 10,07 \\
\hline $3 \mathrm{a}$ & Kata kerja yang berawalan 'ber-' & 17 & 6,34 \\
\hline $3 \mathrm{~b}$ & Lain-lain & 104 & 38,81 \\
\hline Jumlah & & 268 & 100 \\
\hline
\end{tabular}

Data yang ditemukan dikelompokkan dalam beberapa jenis kalimat pasif bahasa Inggris yaitu:

(1) Kalimat Pasif yang pelakunya (doer, agent) tidak dikenal, antara lain seperti followed, Dmitri?" (chapter two, page 17) contoh berikut ini:

(1a) "Do you know we're followed, Mr.Stanford? (chapter one, page 3)

(1b) "Anda tahu kita diikuti, Mr.Stanford?" (bab 1, halaman 11)

(2a) "There are no chance that we were 
(2b) "Kita tidak diikuti, Dmitri?" (bab 2, oleh kru TV RAI dari Italia. (bab 7, halaman halaman 26) 73).

(2) Kalimat Pasif yang pelakunya (doer, (4) Kalimat pasif yang berarti keadaan, agent) tidak jelas atau tidak penting, antara contohnya sebagai berikut.

lain seperti contoh di bawah ini

(3a) You are cleared for take off. (chapter two, page 15)

(7a) She was awed. (chapter two, page 21)

(7b) Sophia terkagum-kagum. (bab 2, halaman 31)

(3b) Anda diijinkan lepas landas. (bab 2, halaman 24)

(4a) His weekends were totally devoted to the children. (chapter four, page 36)

(4b) Akhir pekannya dikhususkan bagi mereka. (bab 4, halaman 45)

(8a) "I'm retired" (chapter three, page 30)

(8b) "Aku sudah pensiun" (bab 3, halaman

(9a) Harry wasn't satisfied with that. (chapter seven, page 53)

(9b) Harry rupanya belum puas. (bab 7, halaman 64)

(3) Kalimat Pasif yang pelakunya (doer, agent) diketahui atau diberi tekanan. Kalimat Pasif yang pelakunya diketahui atau diberi tekanan, contohnya antara lain:

(5a). It is surrounded by a spectacular and enchanting landscape of hills and valleys covered with flowers, orchard and pine forests. (chapter one, page 5)

(5b) ...., dikelilingi bukit-bukit dan lembahlembah yang menawan. (bab 1, halaman $13,14)$

(6a) Capitaine Durer, dressed in an impressive new uniform, was being interviewed by an RAI television crew from Italy. (chapter seven, page 60)

(6b) Capitaine Durer, dengan seragam baru yang mengesankan, sedang diwawancarai

\section{Deskripsi Bentuk Kalimat Terjemahan}

Kalimat dalam bahasa Indonesia dapat dibedakan menjadi kalimat aktif dan kalimat pasif. Penerjemahan kalimat pasif bahasa Inggris ke dalam bahasa Indonesia bisa dalam bentuk kalimat pasif maupun aktif. Bentuk kalimat pasif dalam novel Morning, Noon and Night ini sebagian diterjemahkan ke dalam bentuk kalimat pasif dan sebagian tidak diterjemahkan ke dalam bentuk kalimat pasif. Bentuk terjemahan kalimat pasif sebanyak 54,85\% (kelompok 1 dan kelompok 2). Bentuk terjemahan bukan kalimat pasif sejumlah 45,15\% (kelompok 3). Kelompok 3 yang cukup dominan jumlahnya ini merupakan kalimat aktif. 
Beberapa contoh terjemahan dalam bentuk kalimat pasif yang verbanya berawalan di- adalah sebagai berikut.

(10a). He was accompanied by a strikingly lovely young brunette... (chapter one, page 3)

(10b). Ia ditemani wanita muda..(bab 1 , halaman 11)

(11a). ... I hate to be disturbed on weekends. (chapter four, page 37)

(11b) ... Aku tidak suka diganggu pada hari Minggu... (bab 4, halaman 47)

(12a). Funeral services were to be held three days later. (chapter seven, page 66)

(12b). Upacara pemakaman akan diadakan tiga hari kemudian. (bab 7, halaman 79)

Berdasarkan beberapa contoh terjemahan di atas diketahui bahwa bentuk terjemahan kalimat pasif yang verbanya menggunakan awalan di- memiliki subjek yang dikenai tindakan. Penerjemahannya masih mempertahankan bentuk yang sama. Beberapa contoh terjemahan dalam bentuk kalimat pasif yang verbanya berawalan ter-, antara lain:

(13a) She had been devastated by the news of Woody's marriage, but she was too proud to reveal it. (chapter ten, page 99) (13b) Ia sangat terpukul oleh berita mengenai perkawinan Woody, namun tidak mau memperlihatkannya. (bab 10, halaman 117)

(14a) He was caught, and his brother escaped. (chapter 16, page 202)

(14b) Hal tertangkap, sementara kakaknya lolos. (bab 16, halaman 232)

(15a) The Nielsen family is scattered around the United States, (chapter twentytwo, page 279)

(15b) Keluarga Nielson tersebar di seluruh Amerika. (bab 22, halaman 317)

Bentuk kalimat pasif juga menggunakan verba berawalan ter- yang subjek dikenai tindakan. Ada kalanya penerjemahan tidak bisa mempertahankan bentuk yang sama untuk mendapatkan makna yang sesuai dengan bahasa sumber, penerjemah harus mencari bentuk kalimat lainnya yaitu kalimat aktif. Beberapa contoh kalimat terjemahan dalam bentuk yang bukan kalimat pasif adalah sebagai berikut:

(16a) When they were finished, they made their way back to the villa. (chapter one, page 11)

(16b) Sehabis makan, mereka langsung kembali ke vila. (bab 1, halaman 11)

(17a) By then, he was involved with someone new. (chapter seven, page 54) 
(17b) Saat itu Stanford sudah menemukan wanita lain, dan.. (bab 7, halaman 66)

Berdasarkan beberapa contoh, dapat dilihat bahwa kalimat pasif yang diterjemahkan bukan ke kalimat pasif adalah kalimat yang berarti keadaan atau stative passive (kata kerja past participle sebagai adjektiva) seperti They were finished, dan I'm puzzled by something, Simon.

Jelaslah bahwa bentuk kalimat pasif yang diterjemahkan sebagian adalah bentuk terjemahan kalimat pasif bahasa Indonesia dengan kata kerja berawalan di-, ter-, dan yang bukan bentuk kalimat pasif. Ini menunjukkan bahwa bentuk terjemahan kalimat pasif dalam bahasa Inggris tidak semuanya diterjemahkan ke dalam bentuk kalimat pasif juga.

\section{Analisis Bentuk Kalimat Terjemahan}

Dari temuan penelitian diperoleh data kalimat pasif bahasa Inggris yang berpola kata kerja be + past participle dalam semua bentuk tenses diterjemahkan dan semua jenis kalimat pasif yang diterjemahkan ke dalam bentuk kalimat pasif bahasa Indonesia yang memiliki kata kerja yang berpola kata kerja dengan awalan di- dan yang berpola kata kerja dengan awalan ter-, serta bentuk yang bukan kalimat pasif. Kalimat pasif yang berawalan di- memiliki pelaku, baik yang jelas maupun yang tidak diketahui, seperti pada contoh kalimat 10 sampai dengan 12. Kalimat-kalimat ini merupakan kalimat tunggal (yang memiliki satu klausa) yang memiliki pola subjek + verba pasif (berawalan di-) + objek atau pelengkap. Kalimat- kalimat ini mudah dipahami. Kalimat pasif yang berawalan termemiliki makna unsur ketidaksengajaan, kekodratan ataupun keadaan, seperti pada contoh kalimat 14 dan 15. Kalimat yang memiliki bentuk yang bukan kalimat pasif memiliki pola kata kerja dengan awalan berseperti contoh berikut:

(46a) Both teams were lined up now, side by side. (chapter ten, page 110)

(46b) Kedua tim telah berbaris, berdampingan. (bab 10, halaman 130)

Kalimat tersebut merupakan kalimat aktif dimana subjeknya sebagai pelaku (lihat lampiran 1, kelompok 3).

Bentuk kalimat yang bukan kalimat pasif juga memiliki pola kata kerja kalimat aktif lainnya yang menunjukkan subjek sebagai pelakunya, seperti contoh berikut.

(47a) The newspaper had been filled with the story. (chapter eight, page 70)

(47b) Pihak pers dengan gencar meliputi peristiwa tersebut. (bab 8, halaman 84) 
(48a). Woody was too ashamed to look at the

Jumlah kalimat terjemahan dalam bentuk kalimat yang bukan kalimat pasif $(+/-$ $45 \%$ ) yang kata kerjanya berawalan ber- dan berawalan me- dan yang lainnya hampir menyamai jumlah kalimat terjemahan dalam bentuk kalimat pasif (+/- 55\%) yang kata kerjanya berawalan di- dan berawalan ter-. Hasil temuan ini menunjukkan bahwa penerjemah menyajikan terjemahan kalimat pasif dalam bentuk kalimat pasif maupun kalimat aktif. Kalimat pasif bahasa sumber yang tidak bisa diterjemahkan ke dalam bentuk kalimat pasif, diterjemahkan ke dalam bentuk kalimat aktif, yang memiliki makna yang sama. Seperti pada contoh kalimat 16 dan 17 pada bab IV: was involved yang berarti 'terlibat, tersangkut', tetapi penerjemah menggunakan kata 'menemukan'. Jika penerjemah menggunakan terjemahan 'terlibat' atau 'tersangkut', makna kalimatnya akan kurang pas dan memengaruhi bagian cerita yang ada. Pemilihan kata 'menemukan wanita lain' lebih cocok untuk kalimat ini.

Di sini jelas bahwa penerjemah mengutamakan tingkat kebermaknaan cerita dari pada bentuk kalimat terjemahannya. Penulis juga menemukan sebuah kalimat pasif positif yang diterjemahkan ke dalam bentuk kalimat negatif, yaitu:

\section{others. (chapter ten, page 114)}

(48b). Woody tidak berani menatap mereka. (bab 10, halaman 135)

Was too ashamed memiliki arti harfiah 'terlalu malu'. Frasa ini terlalu kaku jika digunakan dalam kalimat, sehingga penerjemah memilih 'tidak berani' yang memiliki kesan yang sama dengan gaya bahasa yang luwes walaupun dalam bentuk penerjemahan yang berbeda dari bahasa sumber. 'Tidak berani' tidak selalu karena malu, 'tidak berani menatap' bisa terjadi karena takut. Terjemahan ini tidak memengaruhi makna kalimat, tetapi bentuk terjemahan ini tidak bisa mewakili bentuk terjemahan secara keseluruhan karena data yang diperoleh hanya satu.

\section{SIMPULAN}

Berdasarkan hasil dan pembahasan pada analisis perubahan kalimat pasif berbahasa Inggris ke dalam bahasa Indonesia pada novel Morning, Noon and Night dapat disimpulkan bahwa bentuk kalimat terjemahan kalimat pasif dari bahasa Inggris ke dalam bahasa Indonesia adalah dalam bentuk kalimat pasif dan dalam bentuk bukan kalimat pasif (kalimat aktif). Ternyata dari data yang diperoleh terdapat terjemahan kalimat yang bukan kalimat pasif yang jumlahnya hampir sama dengan terjemahan 
kalimat pasif (54, 85\% kalimat pasif dan 45,15\% kalimat aktif). Bentuk terjemahan kalimat pasif disesuaikan dengan makna kalimat. Kalimat pasif yang diterjemahkan ke dalam bentuk kalimat pasif pada umumnya yang memiliki pelaku, baik yang pelakunya jelas maupun yang tidak dikenal. Kalimat pasif yang diterjemahkan ke dalam kalimat yang bukan kalimat pasif adalah kalimat pasif yang berarti keadaan (stative passive). Bentuk kalimat tidak dipengaruhi oleh tenses bahasa Inggris.

Hasil penelitian menunjukkan bahwa kalimat aktif merupakan kalimat yang komunikatif dalam penyajian terjemahan novel agar menarik bagi pembacanya. Oleh karena itu perubahan kalimat pasif dari bahasa sumber tidak harus dilakukan. Penerjemah tidak harus mempertahankan bentuk kalimat pasif dalam bahasa sasaran, namun harus ada penyesuaian makna kalimat yang disampaikan. Bentuk kalimat bukanlah yang menjadi pola utama dalam penerjemahan, melainkan makna kalimat. 


\section{DAFTAR PUSTAKA}

Alwi, H., et al. (2003). Tata bahasa baku bahasa Indonesia. Jakarta: Balai Pustaka.

Azar, Betty Schrampfer. (1989). Undestanding and using English Grammar (2nd Ed). New Jersey: Prentice Hall Regents. (1992). Fundamentals of English grammar ( $2^{\text {nd }}$ Ed). New Jersey: Prentice Hall Regents.

Catford, John Cunnison. 1965. A Linguistic Theory of Translation. London: Oxford University Press.

M.R., Darmawati. 2013.” Alih Bahasa Novel Dear John: Masalah Bentuk dan Makna" dalam Jurnal Ilmiah Kebahasaan Jalabahasa Balai Bahasa Jawa Tengah, Volume 9 Nomor 1, Mei 2013.

Hasibuan, R. S. (1991). Teori terjemahan dan kaitannya dengan tata bahasa Inggris. Jakarta: Dian Rakyat.

Machali, Rochayah. 2000. Pedoman bagi Penerjemah. Jakarta: Gramedia.

Moentaha, S.(2006). Bahasa dan terjemahan. Jakarta: Kesaint Blanc.

Newmark, P. (1981). Approaches to translation. UK: Pergamon Press. (1988). A Texbook of translation. UK: Prentice Hall International. (1991). About Ttranslation. UK: Multilingual Matters.
Nida, Eugene Albert. (2003). The theory and practice of translation. Boston: Brill Leiden.

Sheldon, S. (1995). Morning, Noon and Night. NY: Warner Book.

Setiadi, Hendarto. (2009). Pagi, Siang, dan Malam. Jakarta: Gramedia Pustaka Utama. 
Telaga Bahasa, Vol. 5, No. 1, Juni 2017: 107-126 